\title{
Prevalence and Risk Factors of Cryptosporidium spp. on Dairy Farms in Bogor
}

\section{Prevalensi dan Faktor Risiko Cryptosporidium spp. pada Peternakan Sapi Perah di Kabupaten Bogor}

\author{
Arifin Budiman Nugraha ${ }^{1 *}$, Umi Cahyaningsih ${ }^{1}$, Etih Sudarnika ${ }^{2}$ \\ ${ }^{1}$ Laboratory of Protozoology, Faculty of Veterinary Medicine, Jln. Agatis Kampus IPB Dramaga, \\ IPB University, Bogor \\ ${ }^{2}$ Veterinary Public Health, Faculty of Veterinary Medicine, Jln. Agatis Kampus IPB Dramaga, \\ IPB University, Bogor \\ *Email: arifin@apps.ipb.ac.id
}

Naskah diterima: 9 Mei 2020, direvisi: 4 November 2020, disetujui: 17 Desember 2020

\begin{abstract}
Abstrak
Kriptosporidiosis adalah penyakit yang disebabkan oleh Cryptosporidium spp. yang dapat menginfeksi manusia dan ternak di seluruh dunia. Tujuan dari penelitian ini adalah untuk menduga terdapat infeksi Cryptosporidium serta mengidentifikasi faktor risiko yang berhubungan dengan infeksi Cryptosporidium spp. di peternakan sapi perah di Bogor. Sebanyak 308 sampel feses yang terdiri atas 136 sampel feses dari sapi berumur $<6$ bulan, 43 sampel dari yang berusia antara $6-12$ bulan dan 128 sampel dari sapi berumur $>12$ bulan. Pencatatan dilakukan pada data yang terkait dengan faktor-faktor yang berpotensi dengan kemungkinan infeksi Cryptosporidium spp. yaitu, status lingkungan, jumlah ternak, dan manajemen ternak. Ookista dari Cryptosporidium spp. diidentifikasi dengan menggunakan teknik pewarnaan tahan asam Ziehl Neelsen dan diperiksa secara mikroskopis dengan pembesaran 400x. Hasil penelitian menunjukkan prevalensi kriptosporidiosis di Bogor sebesar 21,1\% (CI 95\%; 16,5\% -25,6\%). Prevalensi tertinggi terjadi pada sapi berumur $<6$ bulan, yakni $29 \%$ (CI 95\%; 26,8\% -31,7\%). Kelimpahan ookista berkisar $<5$ ookista per luas lapang pandang. Analisis statistik menunjukkan bahwa terdapat hubungan antara kriptosporidiosis dengan pedet umur $<6$ bulan dengan Odds ratio (OR) 2,7 (CI 95\%; 1,5-5,2) kali dibandingkan dengan sapi berumur $>12$ bulan. Penelitian ini menunjukan bahwa Cryptosporidium spp. ditemukan di peternakan sapi perah Kabupaten Bogor. Hasil ini memberikan informasi dasar yang penting untuk penelitian selanjutnya. Oleh karena itu, pencegahan dan pengendalian infeksi Cryptosporidium spp. perlu dilakukan untuk mengurangi potensi penularan pada manusia dan hewan.
\end{abstract}

Kata Kunci: Bogor; Cryptosporidium spp.; faktor risiko; prevalensi; sapi perah.

\begin{abstract}
Cryptosporidiosis is an important zoonotic disease caused by Cryptosporidium spp which found infect humans and livestock worldwide. The aim of this study was to estimate the prevalence of Cryptosporidium infection and to identify risk factors related with shedding of oocysts in two dairy farms in Bogor. A total of 308 faecal samples were collected which consisted of 136 faecal samples from cattle aged less than 6 months, 43 samples from those between 6 to 12 months and 128 samples from those above 12 months. Data of factors potentially associated with the likelihood of Cryptosporidium spp. infection were recorded (i.e., environmental status, size of herd, and herd management). Cryptosporidium spp. oocyst was identified by using modified acid fast (Ziehl Neelsen) staining technique and microscopically examined under 400x magnification. Results showed that the prevalence of cryptosporidiosis in Bogor was 21.1\% (CI 95\%; 16.5\%-25.6\%). The highest prevalence was $29 \%$ (CI 95\%; 26.8\%-31.7\%) which was observed in cattle aged less than 6 months. The oocysts abundance were around $<5$ oocysts per microscopy visual area. Data was analyzed using logistic regression models. Statistical
\end{abstract}


analysis showed that there were association between cryptosporidiosis and calves aged less than 6 months with an odds ratio (OR) was 2.7 (CI 95\%; 1.5-5.2) times compared with cattle aged more than 12 months. This study revealed that the Cryptosporidium spp. was present in dairy farm Bogor district. The result provide baseline information for further study. Prevention and control of Cryptosporidium spp. infection needs to be done to reduce the potential of infection to humans and animal.

Keywords: Bogor; Cryptosporidium spp.; Dairy Farm; Prevalence; Risk Factors.

\section{Introduction}

Cryptosporidium species belong to the Aplicomplexa phylum of parasites and has been detected in a wide range of vertebrate hosts. Cryptosporidium is a zoonotic protozoa that infects many different mammals including cattle and humans. Cryptosporidium is recognized as one of the primary pathogens causing diarrhea in neonatal calves (Thompson et al., 2017). This protozoa is transmitted through water, food, and enviromental contamination by its oocysts. Control of environmental contamination by oocysts is difficult because the oocysts are very small $(4-6 \mu \mathrm{m})$ and can survive for months at room temperature (Ramirez et al. 2004).

Cryptosporidiosis is become the concern of the dairy producers due to its the direct losses due to calves not performing well and the potential for environmental contamination. It has been reported that cattle infected with Cryptosporidium losses its weight $0.5 \mathrm{~kg}$ per day. It was suggested that chronic infection in cattle causes gastritis, reduces milk yield and poor weight gain (Anderson1998). These conditions may lead to serious economic losses.

Currently, there is limited of information regarding the prevalence and risk factors for this protozoal parasite in the Indonesian cattle production systems and how the best way to reduce the occurrence of animal infection. In Indonesia, dairy cattle are primarily managed by small farm holders with traditional management systems. It is therefore necessary to improve management approaches in order to prevent the risk of cryptosporidiosis. Cryptosporidiosis prevalences which has been reported from other countries vary from 22 to $59 \%$ (Anderson \& Hall 1982; Castro-Hermida et al. 2006; Brook et al, 2008). While, studies on the prevalence of cryptosporidiosis in Indonesia in beef cattle has been reported in in Bali district 37.4\% (Artama 2005), and in West Java which reported positive for C. andersoni (Ananta 2014). However, the information regarding the cryptosporidiosis prevalence in dairy cattle in Bogor district has not been reported so far. In Indonesia, dairy cattle are primarily managed by small farm holders with traditional management systems. It is therefore necessary to improve management approaches in order to prevent the risk of cryptosporidiosis. The aim of the study is to determine the prevalence of Cryptosporidium infection and its associated risk factors in dairy cattle in the district of Bogor, Indonesia. The aim of the study is to determine the prevalence of Cryptosporidium infection and its associated risk factors in dairy cattle in the district of Bogor, Indonesia.

\section{Materials and Methods}

\section{Study Area}

A cross-sectional study was conducted to identify factors associated with the risk of Cryptosporidium spp. infection in two dairy farms (i.e., Kawasan Usaha Ternak and KUD Giri Tani) district in Bogor, West Java, Indonesia. All animals in the dairy farms are of Holstein-Friesian breed or local breeds crossed with Holstein-Friesian. Faecal samples were collected per rectum from a random selection of calves younger than 6 months, animals between 6 and 12 months and adult cows (>12 months).

\section{Sample Size}

Samplings were conducted in two dairy farm regions (Kawasan Usaha Ternak, Cibungbulang and KUD Giri Tani, Cisarua), with total 3500 animals population. Sample size was determined based on $95 \%$ confident, $50 \%$ expected prevalence, 
and $5 \%$ desired absolute precision. Based on that, a total sample size of 308 samples was determined. The formula for determining the sample size (Thrusfield 2005) is as follows:

$$
\mathrm{n}=\frac{4 \mathrm{pq}}{\mathrm{L}^{2}}
$$

$n$ : required sample size

$p$ : expected prevalence

$q:(1-p)(1-p)$

$L$ : desired absolute precision

\section{Sample collection}

Those samples were taken from the rectum of each animal and put into separate plastic bags. The plastic bags were identified based on the farmer's name, age of animal, and animal ear tag and then stored without any preservation at $4^{\circ} \mathrm{C}$ until faecal processing in the laboratory.

\section{Oocyst purification in faeces}

Faecal samples were mixed with Sheater's sucrose floatation, centrifuged at $1500 \mathrm{rpm}$ for 10 minutes, and the upper third of solution (Cryptosporidium oocyst layer) were harvested. A drop of the oocyst suspension was spread onto a microscope slide, cover slipped, and examined for oocysts using phase contrast microscopy at 400x magnification. This method was used as an initial screening tool and to generate a semi-qualitative evaluation of oocyst intensity for the sample. After that, the oocyst layer is combined with 30 to $50 \mathrm{ml}$ of distilled water centrifuged at 1500 rpm for 10 minutes, and the supernatant removed. The sediment layer typically contains many oocysts for positive samples and this purification step dramatically improves the sensitivity and specificity of the acid fast staining procedure defined below.

\section{Modified Ziehl-Nelseen (acid fast) staining of oocysts}

Twenty $\mu 1$ of resuspended faecal sediment was smeared onto a glass slide and air dried overnight. Slides were stained in carbol fuchsin for 5 to 10 minutes, rinsed in tap water for 2 to 3 minutes, and decolorized in acid alcohol (1\% HCL in $70 \%$ ethanol) for 5 seconds. Slides were then rinsed in water for 5 seconds, counterstained with methylene blue for 2 to 3 minutes, and air dried. Using light microscopy, the entire smear was examined at 1000x magnification for Cryptosporidium spp. oocysts (Rosiléia et al. 2006).

\section{Data collection}

A questionnaire was designed to collect data on demographic, general herd management, and health factors hypothesized to be associated with the risk of Cryptosporidium spp. infection in dairy herds. Data were collected by personal interview with the farm owner or worker.

\section{Oocyst abundance}

Oocyst abundance was determined by assessing the average number of oocyst seen per ten fields $(1+=<5$ oocysts per field, $2+=>5$ oocysts per field, $3+=>20$ oocysts per field). Oocysts were identified using 400x magnification and confirmed under 1000x magnification (Banda et al., 2009).

\section{Statistical Analysis}

The SPSS statistical program(Version 6.1) was used to generate descriptive statistics and manage data. Prevalence was determined as the proportion of samples tested positive for Cryptosporidium spp. to those tested negative. Prevalence was examined in the population as a whole, at the herd level and by age. Logistic regression analysis was used to determine association of risk factors and infection of Cryptosporidium spp. Interval prevalence was calculated as follows :

$$
\begin{array}{ll} 
& \hat{p} \pm Z \alpha / 2 \sqrt{\frac{\hat{p}(1-\hat{p})}{n}} \\
\hat{p} & : x / n x / n \\
\hat{p} & : \text { prevalence } \\
x & : \text { positive samples } \\
n & : \text { sample size } \\
\mathrm{Z}_{\alpha / 2} & : \text { normal standard value } \alpha / 2
\end{array}
$$

\section{Results and Discussion}

The number of faecal samples obtained in this study was 308 samples from 3 different age groups. The sample consisted of 136 faecal samples from cattle aged less than 6 months, 43 samples from those between 6 to 12 months and 
Table 1. Prevalence of cryptosporidiosis according to different age groups

\begin{tabular}{lcc}
\hline Ages & Prevalence $(\%)$ & Prevalence Interval $(\%)$ \\
\hline$<6$ months $(\mathrm{n}=136)$ & 29 & $26.8-31.7$ \\
6-12 months $(\mathrm{n}=44)$ & 23 & $18.3-27.7$ \\
$>12$ months $(\mathrm{n}=128)$ & 13 & $12.3-23.7$ \\
Herd prevalence & 21.1 & $16.5-25.6$ \\
\hline
\end{tabular}

128 samples from those above 12 months. The overall prevalence of cryptosporidiosis in the two dairy farms in Bogor was 21.1\% (67/308) (CI 95\%; $13.1 \%-21.5 \%)$ with the respective prevalence in each farm was $17.3 \%$ (CI 95\%; 13.1\% -21.5\%) in Kunak and 24.9\% (CI 95\%; 20\% -29.7\%) in Cisarua. Cryptosporidiosis prevalence data for each region is presented in Table 1.

Table 1 revealed that the highest prevalence was found in cattle aged less than 6 months. Based on microscopic examination with modified acid fast (Ziehl Neelsen) staining, there were 67 stool samples positive for Cryptosporidium spp. from a total of 308 samples. From the 67 positive samples, the average abundance of oocysts was less than 5 oocysts per field of view with $400 \times$ magnifications. Cattle aged less than 6 months was the highest age group infected with Cryptosporidium spp. compared to the other two age groups (6 to 12 months and more than 12 months).

Riskfactoranalysis wasconducted todetermine which variables are risk to cryptosporidiosis. All variables were tested by bivariate (Chi square) to determine the variables candidate. Variables with $\mathrm{p}<0.05$ value was selected candidate variable of risk factors to Cryptosporidium infection. The variables candidate included source of water, diarrhea in cattle, cattle age, duration of diarrhea, faecal disposal sites, and animal density. Furthermore, the six variables were further analyzed using multiple logistic regressions to determine which variables were at risk an incidence risk of cryptosporidiosis in cattle. Calves aged less than 6 months have odds ratio (OR) of 2.7 (CI 95\%; 1.5-5.5) times, compared to cattle aged more than 12 months, but only cattle aged less than 6 months with significant relation $(\mathrm{p}<0.05)$ on the incidence of cryptosporidiosis (Table 2).

Cryptosporidiosis prevalences which has been reported from other countries vary from 22 to $59 \%$ (Anderson \& Hall 1982; Castro-Hermida et al. 2006; Brook et al, 2008), although this depends on the age of the target population and the diagnostic test used. Meanwhile, studies on the prevalence of cryptosporidiosis in Indonesia in beef cattle has been reported in two regions namely in Bali district which reported a prevalence of $37.4 \%$ with the highest prevalence in cattle aged less than 6 months (16\%) (Artama 2005), and in West Java which reported two samples were

Table 2. Risk factors associated with Cryptosporidium spp. in dairy herds in Bogor district

\begin{tabular}{|c|c|c|c|c|c|c|}
\hline \multirow{2}{*}{ No } & \multirow{2}{*}{ Variable } & \multirow{2}{*}{ Number of observation } & \multicolumn{2}{|c|}{ Cryptosporidium spp Oocyst Shedding } & \multirow{2}{*}{$\begin{array}{c}\text { Odds Ratio } \\
\text { (CI 95\%) }\end{array}$} & \multirow{2}{*}{$\mathrm{p}$} \\
\hline & & & Positive & Negative & & \\
\hline \multirow[t]{3}{*}{1} & Feed storage & & & & & \\
\hline & On the floor & 71 & $16(23 \%)$ & $55(77 \%)$ & $1.1(0.6-2.1)$ & 0.79 \\
\hline & Feed storage & 237 & $50(21 \%)$ & $187(79 \%)$ & Reference & \\
\hline \multirow[t]{4}{*}{2} & Age & & & & & \\
\hline & $<6$ months & 136 & $40(29 \%)$ & $96(70 \%)$ & $2.7(1.5-5.5)^{*}$ & 0.002 \\
\hline & 6-12 months & 44 & $10(23 \%)$ & $33(77 \%)$ & $1.9(0.8-4.8)$ & 0.12 \\
\hline & $>12$ months & 128 & $17(13 \%)$ & $112(87 \%)$ & Reference & \\
\hline \multirow[t]{3}{*}{3} & Herd density & & & & & \\
\hline & $<10$ herds & 156 & $35(23 \%)$ & $121(77 \%)$ & Reference & \\
\hline & $\geq 10$ herds & 152 & $31(20 \%)$ & $121(80 \%)$ & $1.1(0.6-1.9)$ & 0.01 \\
\hline \multirow[t]{4}{*}{4} & Waste disposal & & & & & \\
\hline & River & 186 & $45(24 \%)$ & $141(76 \%)$ & $0.6(0.1-3.6)$ & 0.61 \\
\hline & Field & 116 & $19(16 \%)$ & $97(84 \%)$ & $0.4(0.07-2.3)$ & 0.29 \\
\hline & Septic tank (biogas) & 6 & $2(33 \%)$ & $4(67 \%)$ & Reference & \\
\hline
\end{tabular}

note : (*) statistically significant $\mathrm{p}<0.05$ 
positive for Cryptosporidium andersoni (Ananta 2014). However, the information regarding the cryptosporidiosis prevalence in dairy cattle in Indonesia has not been reported so far.

According Fayer et al., (2000), the results of the prevalence of cryptosporidiosis depend on the sensitivity and specificity of inspection methods and the age of the animal sampled. Examination of samples using the modified Ziehl Neelsen method had lower specificity and sensitivity compared to molecular technique. Therefore, to obtain better results, a combination of conventional and molecular examination is needed (Brook et al. 2008). Low levels of oocysts were detected because the samples were taken mainly in weaned cattle as in this period there were a lack of pre-weaned calves. However, the highest number of positive sample was found in calves aged less than 6 months. Age has a high correlation with Cryptosporidium infection, mainly in calves aged between 8 days to 21 days. Brook et al. (2008) reported that calves aged 8 days to 21 days old had 5.24 times at higher risk compared to the older cattle, whileAtwill et al. (1999) reported that calve aged 4 months or less was 13 times at risk compared to older animals.Cryptosporidiosis incidence will decrease when the age increases (Maldonado-Camargo et al. 1998), and it was proven by Doungmala et al. (2019) who observed that the prevalences in young cattles were higher than older animals (12 months to 24 months and more than 2 years). This is perhaps associated with the immunity of the animals where adult animals have a better immunity due to previous exposure to Cryptosporidium infection compared to young animals, which are usually susceptible to initial infections.

Animals and humans can potentially be infected by Cryptosporidium oocysts excreted in faeces of infected cows. Disposal of waste on a dairy farm in Bogor in general has not been implemented properly, because the waste is not disposed off in a special channel. There was evident that farmers were flowed some waste disposal (faeces and food remains) that into the river and the area of plantation. Based on observations, most of the farmers dispose the livestock waste (faeces) directly into the river. Therefore, the reuse of river water poses high risk of infection by Cryptosporidium infection. Sischo et al. (2000) reported that the poor management of surface water which contaminated with cattle manure was one of the potential risk for the spread of Cryptosporidium oocysts. Yoshinori et al. (2001) reported that 6 out of the 10 samples of river water that was along the dairy farm in Hokkaido were positive for Cryptosporidium oocysts. Additionally, Artama (2005) reported that water samples taken from the river water used to bathe the Bali cattle in Karangasem regency were 100\% positive for Cryptosporidium oocysts. However, the examination of Cryptosporidium oocysts in river water was not cinducted in this study. The poor of waste management and disposal were not done properly will be a source of environmental pollution.

Calves are important sources of cryptosporidiosis in herds. The most important thing that calf infected by oocysts was when the farmer provides colostrum. Calves can be infected by Cryptosporidium oocyst at any time after birth. Shortly after calves are born, farmer will directly give colostrum from the cow. If the farmers did not clean the udders properly when milking the colostrum, the dirt/contaminant attached to the udder can be a source of contamination to the colostrum. The farmers in Bogor usually gave colostrum in the bucket and assisted by hand to stimulate the calf to drink. However, generally farmers in this area do not pay attention to good personal hygiene such as washing hands properly before giving the colostrum to the calves. Maldonado et al. (1998) reported that the way the colostrum was fed to calf was related to incident of cryptosporidiosis. Another study reported that calves infected by oocysts of Cryptosporidium were the first hour post birth caused by environmental contamination by oral route (Naciri et al. 2011).

Furthermore, there were two sources of water used by the farmers for their activity, one from rivers and the other from springs. The used of river water was risk of Cryptosporidium infection. Because one of the transmission of Cryptosporidium oocysts was through water. It is known that the water of the river was a collection of fecal waste water from various places, one of which the waste water from dairy farms. In addition, many farmers stated that the source of water used was never checked periodically 
for filtration and chlorination. Therefore, it is recommended to farmers one precaution against the possibility of contamination of oocysts in water sources used by breeders do a double check water for Cryptosporidium oocysts spp. Korich et al. (1990) reported that the use of ozonation and chlorin dioxide for the water was able to reduced the viability and infectivity of Cryptosporidium oocysts. In addition, the use of disinfectants in combination was much better than the used single disinfectants.

There are 5 risk factors associated with cryptosporidiosis such as herd density, number of milking cows, presence of animals other than cattle on the farm, the distance of the barn from the house septic system, and animals' age (Nydam \& Mohammed 2005). In this study, the farmers raised the animals in groups and not in individual pen. This management practice will increase the risk of Cryptosporidium infection, because if one of the animals gets infected with cryptosporidiosis, the infected animal can be a source of infection for other healthy animals.

\section{Conclusions}

Prevalence of cryptosporidiosis in dairy farms in district of Bogor district was 21.1\% (CI 95\%: 16.5\% $-25.6 \%$ ) with the highest prevalence in cattle aged less than 6 months, is $29 \%$ (CI 95\%: $26.8 \%-31.7 \%$ ). The cattle aged less than 6 months have Odds Ratio 2.7 (CI 95\%; 1.5-5.5) times compared than other age groups. Cryptosporidium oocysts abundance in general is still in the low range (less than 5 oocysts per field of view. Therefore, the prevention and control the danger of infection Cryptosporidium infection needs to be done to reduce the potential of infection to humans and decrease the mortality of young animal due to parasites.

\section{References}

Anderson, B.C., Hall, R.F. (1982). Cryptosporidial infection in Idaho dairy calves. $J \mathrm{Am} \mathrm{Vet}$ Med Assoc. 181: 484-485.

Anderson, Bruce, C. (1998). Cryptospoidiosis in bovine and human health. $J$ dairy $S c i$. 81: 3036-3041.

Artama, I.K. (2005). Cross Sectional Study of Cryptosporidiosis for Bali Cattle in Karang
Asem Bali. Thesis. Faculty of Veterinary Medicine, IPB University.

Atwill, E.R., Johnson, E.M., Pereira, M.G. (1999). Association of herd composition, stocking rate, and duration of calving season with fecal shedding of Cryptosporidium parvum oocysts in beef herds. J Am Vet Med Assoc. 215: 1833-1838.

Ananta, M.S., Suharno, Hidayat, A., Makoto, M. (2014). Survey on gastrointestinal parasites and detection of Cryptosporidium spp. on cattle in West Java, Indonesia. Asian Pac J Trop Dis. 7: 197-201.

Banda, Rosely, A.B., Nichols, A.M., Grimason, Smith, H.V.(2009). Cryptosporidium infection in non-human hosts in Malawi. Onderstepoort J Vet Res. 76: 363-375.

Brook, E., Hart, A., French, N., Christley, R. (2008). Prevalence and risk factors for Cryptosporidium spp. Infection in young calves. Vet Parasitol. 152: 46-52.

Castro, Hemida, J.A., Caroo, Corral, Gonzales, W, Mezo, M. (2006). Prevalence and intensityof infection of Cryptosporidium spp and Giardia duodenalis in dairy cattlein Galicia. J Vet Med. B. Infect Dis. Vet Public Health. 53: 244-246.

Clark, D.P., and Sears, C.L. (1996). The Patoghenesis of cryptosporidiosis. Parasitol Today. 12: 221-225.

Doungmala, P., Phuektes, P., Taweenan, W., Sangmaneedet, S., Japa, O. (2019). Prevalence and species identification od Cryptosporidium spp. In the newborn dairy calves from Muang District, Khon Kaen Province, Thailan. Vet World. 12(9): 1454 1459.

Fayer, R., U. Morgan, and S. J. Upton. (2000). Epidemiology of Cryptosporidium: transmission, detection and identification. Int $J$. Parasitol.30:1305-1322.

Korich, D.G., Mead, J.R., Madore, M.S., Sinclair, N.A., Sterling, C.R. (1990). Effects of ozone, chlorine dioxide, chlorine, and monochloramine on Cryptosporidium parvum oocysts viability. Appl Environ Microbiol . 56: 1423-1428. 
Maldonado-Camargo, S., Atwill, E.R., SaltijeralOaxaca, J.A., Herrera-Alonso, L.C. (1998). Prevalence and risk factors for shedding of Cryptosporidium parvum in Holstein Freisian dairy calves in central Me'xico. Prev Vet Med. 36: 95-107.

Naciri, M., Mancassola, R., Fort, G., Danneels, B., Verhaeghe, J. (2011). Efficacy of aminebased disinfectant KENO COX on the infectivity od Cryptosporidium parvum oocycts. Vet Parasitol. 179 : 43-49.

Nydam, D.V., Mohammed, H.O. (2005). Quantitative risk assessment of Cryptosporidium species infection in dairy calves. J.dairy Sci. 88: 3932-3943.

Ramirez, N.E., Ward, L.A., Sreevatsan, S. 2004. A review of the biology and epidemiology of cryptosporidiosis in humans and animals. Microbes and Infection. 6: 773-785.

Rosiléia, M, De Quadros, Sandra, M.T., Marques, Camila, R., Amendoeira, Larissa, A., De Souza, Paula, R., Amendoeira, Carla, C. (2006). Comparison detection of Cryptosporidium oocysts by auramine and Ziehl Neelsen staining methods. Parasitol Latinoam. $61: 117-120$.
Sischo, W.M., Okhuyen, P.C., Atwill, E.R., Lanyon, L.E., George, J. (2000). Cryptosporidiaon dairy farms and the role these farms may have in contaminating surface water supplies in the northeastern United States. Prev Vet Med. 43: 253-267.

Thrusfield M. (2005). Veterinary Epidemiology. 3rd ed. Iowa, United States of America.

Thompson, S., Hamilton, C.A., Hope, J.C., Katzer, F., Mabbott, N.A., Morisson, L.J., Innes, E.A. (2017). Bovine cryptosporidiosis: impact, host-parasite interaction and control strategies. Vet Research. 48:42.

Yoshinori, T., Panagiotis, K., Takenori, K., Hideyuki, N.H., Xuenan, X., Ikuo, I., Kozo, F., Eiki, T., Takeshi, M. (2000). Detection of Cryptosporidium parvum oocysts in enviromental water in Hokaido, Japan. $J$ Vet Med. 63: 233-236. 